\title{
INOVASI PEMBELAJARAN DI ERA COVID-19 BERBASIS BUDAYA LOKAL PADA PENDIDIKAN INDONESIA
}

\author{
Junaidi \\ Program Studi Pendidikan IPS, FKIP Universitas Lambung Mangkurat \\ Email: Junaidijaya675@gmail.com
}

\begin{abstract}
ABSTRAK
Pendidikan Indonesia semakin tahun semakin bagus dengan dibekalinya guru pendidik yang semakin profesiollitas, pendidikan semakin berkembang dari beberapa abad hingga sekarang abad-21 menuju abad-22, pendidikan membawa pengaruh pada pembelajaran. Pembelajaran kian hari dirasa bagus dengan adanya penyebaran corona virus di Indonesia, pembelajaran yang semula dirasa peserta didik biasa-biasa saja kini semakin tertantang penggunaan teknologi informasi dan komonikasi (TIK) daring atau online, pembelajaran daring menciptakan keutuhan pada konteks pembelajaran baru pada kurikulum yang diterapkan di Indonesia seperti perubahan kurikulum 2013, terasa sempurna diterapkan pada era covid-19 dirasakan dilihat dari system media belajar dan atau sumber belajar yang di rubah dengan, penyesuaian kondisi lingkungan. Pembatasan diterapkan berbarengan protocol kesehatan agar penyebaranya tidak terlalu marak peraturan menteri pendidikan membuatkan semua aktifitas pendidikan digantikan aktifitas dirumahkan tujuan agar tidak menghilangkan system belajar baru. Guru pendidik menginovasikan pembelajaran disetiap materi memasukan lokal budaya di daerah sekitar seperti di kota Banjarmasin lengkap budaya lokal mudah diterapkan dan dipahami peserta didik pada lingkunganya langsung.
\end{abstract}

Kata Kunci: Pembelajaran; covid-19; dan budaya lokal;

\section{PENDAHULUAN}

Dalam pembelajaran pendidikan Indonesia semaksimal mungkin mengupayakan agar terus maju dengan latar belakang kekurangan sehingga tidak begitu relevan untuk dikembangkan seorang pendidik seperti halnya guru, hal ini perlu juga adanya kemampuan yang baik memperkaya guru agar semakin profesional dan mengembangkan pembelajaran dengan baik seperti, halnya memperoleh informasi secara mendalam dari beberapa hal sehingga, dapat meningkatkan antusias belajar peserta didik dengan baik. Pendidikan dapat mengubah pemikiran agar bisa lebih kritis dan kreatif sehingga dapat menciptakan suatu perubahan pada nasionalisme dengan mengembangkan kepedulian, sosial, menyelidiki, membuat, memperkaya dan menginformasikan dengan baik semua hal tercantum pada pembelajaran yang diberikan guru, (WARMANSYAH ABBAS, E. R. S. I. S.). 
Pendidikan Indonesia bagaimana pun keadaanya selalu berlanjut keterkaitan pembelajaran seperti ruang dan, waktu relasi antara manusia dengan lingkungan dan, alam mendapatkan tempat secara nyata. Pembelajaran di dalam pendidikan menciptakan manusia sebagai masyarakat berahlak baik sosial dan bersifat mengarah kedepan seperti halnya penyesuaian pembelajaran sekarang pada pelajaran dibangun sebagai perpacuan antara cakupan dari ilmu seperti manusia dan lingkungan, dan teori praktik yang sering dikaji dalam berbagai sosial perdebatan, ditilik dari cakupan kehidupan yang dikaji. Kemudian terjadi perubahan sistem belajar sehingga menjadikan sebuah tantangan pendidikan untuk mempertahankan dalam penyesuaian agar pembelajaran memiliki peran pada penggaruh peserta didik dengan adanya materi ajar sesuai karakteristik, lingkungan, dan kecukupan peserta didik akan isu sosial seperti adanya covid-19 yang menyebar di Indonesia sudah dapat dimengerti, (ABBAS, E. W., Hidayat).

Berdasarkan aturan undang-undang, no.20 th 2003 Pasal 1 (19) Pendidikan Indonesia bagaimana pun keadaanya selalu berlanjut pada seperangkat ketaan aturan atas dasar bahan pelajaran, isi, dan hakikat tujuan, teknik serta ini berguna baik berdasarkan pedoman program kegiatan pembelajaran untuk mencapai makna dasar dari pendidikan. Pembelajaran dilaksanakan pada penerapan saintifik yang cocok diperankan dalam kurikulum orientasinya ditujukan pada peserta didik. Peserta dibawa untuk melihat kehidupan masyarakat langsung akan permasalahan/isu dari konflik bersifat kontekstual. Selutuh kegiatan ajar tidak hanya menyentuh segi kognitif, tetapi juga belajar sesuai persfektif psikologis, (Syaharuddin, S., \& Mutiani, M strategi pembelajaran).

Pendidikan Indonesia beberapa kali terjadinya perubahan pada konteks K13 yang penerapanya berbasis sikap, kemampuan, keterampilan, maupun pengetahuan dibentukkan kepada peserta didik agar dapat menekankan hubungan dengan baik antara keberagaman budaya sehingga menjadikan landasan pengetahuan lokal, tantangan abad 21 yang serba mengalami pergeseran hingga ke dunia pendidikan termasuk pembelajaranya dengan, memperkaya konten budaya lokal peserta didik didalamnya agar bisa dimanfaatkan dengan bijak seperti halnya pembelajaran yang kontekstual, didesainkan guru jaman sekarang secara berkelanjutan untuk meningkatkan kualitas penguasaan materi pembelajaran dengan baik dengan menginovasi pembelajaran berbasis covid-19 yang didorong lebih kreatif dalam pembelajaran berbasis daring, (Abbas, E. W., Handy).

Pembelajaran berbasis daring dilatar belakangi dari pengaruh Pendidikan yang disebabkan dari isu permasalahan yang muncul sekarang berupa Virus Corona atau yang sering disebut dengan Coronavirus, Diesease-19 (covid-19), suatu penyakit disebabkan dari 
virus corona atau cocoknya akan sebutan Severe Acute Respiratory, Syndrome coronavirus2. Virus ini merupakan virus yang telah ditemukan persebaranya kemudian, menyebar ke berbagai negara diantaranya indonesia. Tidak hanya melemahkan jasmani manusia namun melemahkan seluruh aktivitas sosial manusia, menyebabkan pembelajaran pada pendidikan dirasakan kurang efektif dari bersekolah seperti umumnya, ketakutan akan hal ini mengaduk-aduk pikiran, tanpa suara semua kalangan.

Tindakan apapun sulit dan tidak mampu mengusir ketakutan akan tertularnya covid-19, sehingga dengan hal ini merasuk pada covid-19 ketika menyebar pada Indonesia dengan puncak di maret 2020, pemerintah menyebarkan kebiasaan akan adanya WFH work from, home supaya penyakit akan ini berkurang dan, sulit merambak secara sosial. Respons dunia pendidikan medorong supaya pembelajaran online atau daring. Pendidikan seluruhnya 'dirumahkan dengan dialihkan berkegiatan baru dalam belajar pada suatu tempat tinggal seperti rumah konsekuensi ini dampak dari pengaruh adanya suatu kebijakan WFH social and, fisical distancing dapat berjalan untuk mengurangi penyebaran virus, Syaharuddin. Pemerintah Indonesia didukung menteri pendidikan mengeluarkan kebijakanya agar bisa diterapkan pendidikan.

Seperti halnya membangun kepercayaan diri dan menyakinkan, bahwasanya memberikan kesempatan untuk merumahkan peserta didik agar sekolah dan, belajar dirumah memperhatikan jarak kesehatan seperti protokol kesehatan, dengan demikian peserta didik berperan dan bertanggung jawab belajar seperti layaknya di sekolah dengan berkegiatan dan berpikiran fositif, (ABBAS, E. R. S. I. S. 20).

\section{PEMBAHASAN}

Pendidikan Indonesia dituntut untuk dapat mempertahankan hingga memajukan bangsa melalui pembelajaran yang diberikanya sekarang lebih memiliki peran penting dalam materi belajar, peserta didik mampu dibuat guru agar mereka lebih tertarik belajar dalam budaya lokal seperti, dibidang ilmu pengetahuan sosial yang berperan penting untuk di pelajari dan dipahami dengan lingkungan, tempat tinggal sosial budaya mereka yang lebih bermakna, (E. R. S. I. S., \& Syahruddin 2018). Proses pembelajaran diterapkan seperti halnya dengan mengunakan metode ceramah, Tanya jawab, diskusi, dan evaluasi pembelajaran. kiranya sekarang lebih efektif dalam budaya lokal agar mereka dapat belajar dengan santai serta tidak memaksakan untuk mengerti materi yang diajarkan.

Pelaksanaan pembelajaran online kian hari terus berjalan tanpa terputus hitungan bulan maret-mei 2020 masalah. kendala dirasa besar dengan menghadapi peran, mulai dari 
teknis hingga jalanya akan pembelajaran yang baru yang terjadi atas dasar jaringan, biaya koneksi yang mengocek kantong dalam operasional aplikasi smart gadged dengan, prosedur yang benar, ditampilkan saat File maupun PPT, masih kurangnya akan kesadaran peserta didik akan pembelajaran. Implementasi yang dapat diberikan dan dilakukan seperti halnya akan keadaan sekarang dengan hadirnya pandemi covid-19 berpengaruh pada hikmahnya individu akan kualitas kemampuan guru sebagai pendidik dengan peran aktif orang tua di rumah, (Wahyuningsih, S., Abbas, E. Impementasi).

Pembelajaran daring menjadi teknologi informasi yang aktif pada suatu peran dalam pembelajaran. metode secara konvensional diberikan seperti halnya untuk patud dibanggakan atas dasar metode yang kiranya sering dilakukan berupa ceramah tetapi, dominanya pada saat sekarang diperlukan akan adanya "kewajiban" dengan pelaksanaan pembelajaran jarak jauh seperti halnya akan platform tersedia gratis. Dapat menjadikan manusia sebagai pembelajar dengan mendapat kunci akan suatu hasil pembelajaran era penyakit virus seperti ini kita berperan dengan perbanyak belajar informasi akan adanya teknologi. Pembelajaran didefinisikan dari sudut konsepsi pembelajaran behavioristik. Pandangan mengatakan pembelajaran sebagai proses perubahan tingkah laku peserta didik melalui pengoptimalan lingkungan stimulus.

Pendidikan memproses akan suatu interaksi antar peserta didik dengan pendidik secara baik sebagaian akan sumber, dan lingkungan belajar dalam konteks pendidikan berlandas sebagai peran untuk membentuk akan suatu pengetahuan, keterampilan dan sikap, (Syaharuddin, S., \& Mutiani, M. (2020)). Disini guru sangat berperan dengan adanya kebijakan menteri pendidikan sehingga model k13 terelialisasikan dengan baik dari sebelumnya yang dilihat dari komponen pembelajaran didalamnya mencakup aksi guru dengan, peserta didik terkoneksi dengan baik.

Melalui pembelajaran penerapan baru dirasakan kedua komponen ini diantaranya pada kondisi daring yang mengubah peran guru untuk menginovasikan bahan ajar, sumber maupun media penyesuaian kondisi sekarang dengan peserta didiknya sehingga pembelajaran kian lebih menantang, bermakna dan aktif kecocokan bahan ajar baru dipelajarkan pembelajaran sekarang seperti halnya yang berkaitan lingkungan sekitar pada mata pelajaran sekolah, (Syaharuddin, S., \& Mutiani, M). Budaya pada pembelajaran secara lokal seperti halnya pada materi pembelajaran daring didalamnya memuat lingkungan maupun ekologi serta terkait akan kearifan lokal dalam kebudayaan sekitar peserta didik sehingga lebih pantas dimasukan pada pembelajaran di era sekarang. 
Dengan begitu guru berperan untuk memasukan budaya lokal sekitar seperti halnya akan memperkaya pemahaman tentang salah satu, konsep sosial yang mencakup keunikan budaya lokal masing-masing di dalamnya yang dapat dimengerti dan, dapat diperkaya dengan mengamati tanpa mengabaikan pembelajaran yang diberikan guru. Pandangan di perkuat oleh, junaidi 2020. Pembelajaran di Indonesia di integrasikan dengan materi lokal dalam pembelajaranya, agar dapat menciptakan suatu kehormatan dan keberagaman yang menjadikan kekhasan nasionalisme jati diri bagsa pada peserta didik melalui pemanfaatanya dengan penomena yang digunakan dalam sumber belajar.

Yang dapat dilakukan guru melalui pembelajaran ilmu pengetahuan sosial yang didalamnya mencakup keseluruhan termasuk budaya lokal agar bisa memperkaya pemahaman, pegertian, dan pemanfaatan pengetahuan yang dimiliki peserta didik dengan baik sehingga konseptual, faktual dan lebih prosuderal dengan pembekalan yang diberikan guru kepada peserta didik melalui ilmu pengetahuanya, teknonya, sentuhanya akan humaniora berlatar belakang budaya dengan melatar belakangi luas cakupan manusian, negaraan dan maupun kebangsaan, sfesifiknya lagi seperti halnya membahas muatan lokal yang mengkaji kebudayaan banjar yang terjadi dikalimantan pada masa neolitikum.

Muatan budaya lokal yang cocok pada budaya Kalimantan sekarang di kota Banjarmasin dideskripsikan melalui objek wiasatanya seperti akan adanya keberadaan mascot di kota seribu sungai berupa patung bekantan yang dapat berkontrobusi menjadikan sumber pembelajaran yang kiranya cocok pada kondisi sosial maupun kondisi lingkungan sekitar alamnya, yang dapat menjadi subjek saat dimasukanya pada materi ajar, (Ajidayanti, A., \& Abbas, 2019). Kemudian di sampaikan dalam berbagai versi yang dimuat langsung di lingkungan sekitar seperti halnya cerita rakyat sehingga menjadi kearifan bagi masyarakat sekitar, (E. R. S. I. S., \& Syahruddin 2018).

Pembelajaran dijelaskan guru dengan langsung memberikan gambaran yang dapat dimengerti peserta didik dengan baik dengan adanya peraturan psbb maka pembelajaran menyesuaikan dengan, keperluan sekarang sehingga dapat mengaksesnya melalui daring internet peserta didik mengenal bentuk nyata mudah ditemukanya dilingkungan sekitar. Bentuk nyata dari pembelajaran berbasis daring di masukan dalam sumber pembelajaran ilmu pengetahuan sosial dalam skala budaya lokal, seperti halnya pada pendidikan di kota Banjarmasin memuatkan pada pembelajaran dengan menerapkan ekologiwisata sungai dan/atau perairan kota Banjarmasin menjadi pembelajaran.

Biasa saja pendidikan menanggapi setiap tingkatan agar terus deprogram maupun diselenggarakan pada akan suatu sistematis menuju kepada pencapaian pendidikan global. 
Percampuran pada segi muatanya mencakup akan adanya nilai budaya yang dicari pada masyarakat agar dapat menghasilkan insan Indonesia yang berguna atas dasar kecerdasan kompetitif serta menghadapi kemampuan daya saing akan nasional/ internasional. Pada akhirnya, perubahan itu berakibat pudarnya akan suatu pemahaman generasi muda maupun pengalaman terhadap jenis budaya baru sehingga dengan hal ini perlu adanya pembelajaran yang diterapkan pada saat covid-19, potensi mengarah peran anak bangsa memiliki hak untuk memiliki akan suatu jati dirinya pada bangsa dengan identitas kultur nasional maupun budaya lokal, (Subiyakto, B., \& Mutiani, M 2020).

Atas dasar sikap positif dalam belajar demikian peserta didik dilatih agar mapu dan bisa menemukan sendiri dengan dapat berbagai akan suatu konsep pembelajaran. pendekatan pembelajaran perpadu dengan program didalam pembelajaranya diurut pada berbagai cakupan ilmu pada rumpun sosial (Mutiani \& Faisal, 2019). Tuntutan menuntut kehidupan pada global agar terus dapat berkaitan dengan mengkualitaskan pengetahuan mengarah pada bentuk kecakapan ini kemudian membuat pengetahuan harus dilandasi dengan segala hal lainya. Kiranya dimanfaatkan guru untuk pengintegrasian pembelajaran daring dengan Pengembangan yang mungkin bisa dilakukan adalah antara lain.

Pengamatan langsung terhadap hewan dan tanaman, pencarian potensi-potensi kawasan tinggal dan kebun-kebun punya masyarakat atau penduduk sekitar, bentuk wisata edukatif yang bermanfaat yang dilakukan di sepanjang aliran sungai, (ABBAS, E. W., Hidayat Putra, M. A., \& Noor Handy 2019). Sehingga hal ini dijadikan pembelajaran yang mampu lebih efektif untuk dapat dilihat dan diambil tindakan tentang kepedulian sosial langsung yang diterapkan oleh peserta didik di lingkungan sekitarnya seperti halnya menjaga semangat patriotisme dan nasionalisme dapat diciptakan melalui pembelajaran yang kemudian diInovasikan dalam pembelajaran sosial.

Penginovasian pembelajaran dilakukan melalui eksplorasi sumber belajar dengan memanfaatkan potensi lokal yang bisa dimanfaatkan pada potensi dan orientasi lingkungan setempat, peserta didik telah bisa diwujudkan kesadaran sosial menuju masyarakat demokratis dan bertanggung jawab pada peran atas dasar potensi lokal. Bukti dari kearifan lokal masyarakat berperan aktif saat tetapi, bentukan lokal dibentuk untuk diterapkan pada kegiatan aktivitas yang muncul dengan nilai yang bermanfaat pada saat keberlangsungan praktik pembelajaran, (Subiyakto, B., \& Mutiani, M 2019). Kepedulian sosial berkaitan dalam pembelajaran disebabkan tingkat efektivitas dan efisiensi perubahan terknologi dan transportasi yang membawa pengaruh. 
Pengaruh membawa pembelajaran seperti halnya meningkatkan kemampuan peserta didik dengan baik untuk memanfaatkan keilmuan yang diberikan untuk meningkatkan kebutuhan peserta didiknya, keperluan akan materi, budaya, dan kejiwaannya, dapat dimanfaatkan pada sumber daya yang ada dipermukaan bumi dengan benar, atas dasar kesejahteraan yang telah diperankan pemerintah pada keperluan akan kerangka suatu pertahanan tatanan kehidupan hingga membawa pengaruh pembelajaran, (Mutiani, M., Subiyakto 2019). Tidak merusak lingkungan sekitar kenyataan dapat diterapkan pada disiplin ilmu-ilmu sosial.

Kenyataan disiplin ilmu seperti tata negara, sosiologi, antropologi, ekonomi, sejarah, dan geografi. Di tingkat pendidikan kota Banjarmasin maupun Indonesia. Sumber belajar di artikan dengan anggapan sarana. Sarana seperti buku atau bahan ajar di manfaatkan guru bentuk buku sedangkan inovasi yang bisa dilakukan guru pada jaman sekarang pada era covid-19. Memanfaatkan media E-lektronik seperti inovasi buku beralih ke e-book, didalamnya lebih terkesan simple dan tidak memerlukan banyak tempat dan bahkan saat ini lebih bermanfaat dengan adanya inovasi terbaru peserta didik memanfaatkan media sosial dengan bijak.

Kebijakan didasari keperluan akan informasi bahan bacaan mengembangkan kreatifitas belajarnya seperti jurnal, Koran, bulletin, majalah hingga media seperti tv, dan radio kini semakin bermanfaat, (ABBAS, E. W., Hidayat Putra, M. A., \& Noor Handy 2019). Unsur pendidikan Indonesia sudah diterapkan pada pembelajaranya seperti sumber pembelajaran yang di update guru agar peserta didik tidak ngeh atau, bosan Semangat belajar dibentuk dari pesan yang dimuat guru pada pembelajaran agar, peserta didik mengerti pengaruh covid-19 sekarang sumber belajar teralihkan agar peserta didiknya memanfaatkan pembelajaran dengan baik pada tingkat partisifasi belajarnya.

Pembelajaran berbarengan dengan adanya covid-19 di manage dengan ketangguhan semua psikologi kalangan seperti guru dan peserta didik dengan melakukan beberapa tindakan yang dapat memelihara dan lebih fositif lagi dari pada sebelumnya, seperti menyokong asupan mengenai bahan ajar yang cocok kiranya dibahas dan dipelajari peserta didik dengan keterkaitan lingkungan sekitarnya, dengan membekali nasehat agar dapat menjaga protokol kesehatan agar peserta didik tidak berkeliaran diluar semena-mena dengan beranggapan sekolah libur maka dari itu guru memberikan asupan yang kiranya simple untuk diringankan, (ABBAS, E. R. S. I. S. 2020. Menulis).

Partisifasi belajar agar tidak menurun sehingga bahan ajar diberikan menjadi semangat untuk di mengerti pengaruh adanya teknologi dimanfaatkan dengan menyokong 
pembelajaran layaknya sekolah seperti video atau whatshapp sehingga teknik dianjurkan sesuai keperluan peserta didik terpenuhi dengan lingkungan agar peserta didik mengerti, dan menerima keadaan sekitar masyarakat menjadi tempat yang menyenangkan untuk belajar seperti layaknya di sekolahan atau di perpustakaan dapat dimanfaatkan peserta didiknya, (ABBAS, E. W., Hidayat 2019). Arah pembelajaran sosial ditujukan kepada kesadaran lingkungan sekitar.

Insfastruktur yang dibangun pada maskot bekantan di siring kota Banjarmasin selain bermanfaat pada objek wisata di kota berlatar belakang juga dengan insfrastruktur yang dibangun dengan, penyediaan fasilitas umum yang bermanfaat sebagai sumber, dan media belajar yang dapat dimanfaatkan peserta didik di lingkungan sekitar dengan, memanfaatkan fasilitas umum yang telah tersedia seperti wifi, kursi taman dan tempat parkir yang strategis sehingga keamanan dan keuntungan didapatkan, dari tempat objek wisata dibanjarmasin sering dimanfaatkan sebagai pembelajaran pada acara tertentu, (Ajidayanti, A., \& Abbas, E. W. 2019).

Objek diwisata dimasukan dalam kearifan lokal ke dalam kegiatan ekonomi yang dirasakan pada bagian dari kehidupan ekonomi pada masyarakat sekitar. Pemanfaatan sosial dan ekonomi peran hidup masyarakat akan suatu air seperti halnya berperan sebagai sumber yang memiliki makna tujuan dalam seluruh dasar bagi peserta didik atas dasar potensi yang aktif atas keberbentukan akan suatu jati diri dan bangsanya, Begitu pentingnya bagi masyarakat sehingga berkembang suatu budaya baru sebagai ekosistem sungai yang dapat dibericarakan guru kepada peserta didik melalui pembelajaranya, berpengaruh pada setiap kehidupan masyarakatnya, (Putro, H. P. N., \& Jumriani, J. 2020).

Sistem pendidikan mencakup masukan, yang diproses dalam pendidikan, dengan membentuk kehidupan baru akan tatanan kehidupan manusia yang berkualitas sesuai tujuan dari makna pendidikan nasional maupun global. Suatu komponen pendidikan pada peserta didik ditinjau sebagai atas dasar berbagai pendekatan lainya dengan pendekatan psikologis, sosial, dan pedagogis yang mengedukatif, (Syaharuddin, S., \& Mutiani,).

Pengalihan fasilitas umum sekarang merubah sosial dan budaya sekitar karena kehadiran covid-19 diinovasikan pemerintah daerah setempat kepada penduduk dan guru sehingga dapat diterapkan lagi pada peserta didik bukan hanya seakan ajang objek wisata tapi pembelajaran tentang lingkungan yang dapat di analisis dengan mengemukakan pembelajaran yang berbasis aktifitas masyarakat yang dapat digunakan dalam ruang dan kegiatan, Peserta didik dapat mengkaji peningkatan orientasi pengaruh pembelajaran 
dengan, berbasis ekosistem yang diterapkan guru dengan memperhatikan kecocokkan antara materi dengan lingkungan sekitar yang penuh dengan air sungai.

Kecocokan dapat memiliki hubungan secara baik dengan memperhatikan materi pembelajaran yang digunakan sebagai sumber belajar yang relevan sehingga dapat membentuk interaksi sosial didalam aktifitas pembelajaran daring dengan baik seperti akan adanya kegiatan yang didakan guru dalam webinar atau presentasi yang diikuti semua kalangan termasuk peserta didik, smp dan sma, (Handy, M. R. N., Shaleh, R. M., \& Hadi, 2020). Pembelajaran yang melibatkan ekosistem air dimasukan pada materi ajar geografi dan maupun sosiologi yang mencakup bahan ajar potensi sumber daya alam yang dapat dimanfaatkan pada flora dan fauna sebagai keragaman budaya lokal sekitar pada covid-19 sekarang sehingga pembelajaran dapat dianalisis peserta didiknya melalui gambaran aktifitas masyarakatnya.

Peran guru dalam upaya peningkatan pembelajaran dilihat pada kualitas kenampakan yang terjadi antara guru dengan peserta didik dengan menciptakan suatu kenyamanan atas terjadinya suatu kendala yang tercipta didalam pembelajaranya, kendala disini disadarkan kepada dua-duanya antara guru dan peserta didik agar mengerti akan adanya peran yang menginternalisasi nilai-nilai karakter pada peserta didik agar dapat memahami kondisi longkungan sekitarnya, (E. R. S. I. S., Syaharuddin, S., \& Susanto, H.2019. Penerapan Transcript).

Budaya lokal membentuk persepsi sosial baru dalam pembelajaranya, dengan mengenali kualitas kemampuan peserta didik secara optimal dan efesien, sehingga kemampuan akan ketergantungan pada masa kini kian melekat dengan perkembangan teknologi dalam menunjang pembelajaran dengan begitu kegiatan belajar terjalankan dengan baik seperti halnya di sekolah umumnya. Dengan menunjukkan sikap dan perilaku simpatik memperlihatkan baik, semangat dalam mengajar. Lingkungan rumah orang tua terhadap anak memberikan fasilitas ruang belajar dirumah agar anak lebih bersemangat untuk rajin belajar. Kemudian lingkungan masyarakat memperngaruhi pola ajar anak, 9Mutiani, R., \& Suyadi, S.2020. Diagnosa Diskalkulia).

Asupan belajar tidak akan menjadikan beban belajar kepada peserta didiknya dengan, memberikan setiap sesi dengan penugasan baik kelompok maupun individu selayaknya sekolah seperti di rumah. Pembelajaran era covid seperti ini dapat di manage oleh peserta didik dan jika peserta didik tidak mampu maka tidak mustahil dibantu oleh kedua orang tuanya atau guru sekolahnya untuk mencarikan solusi atas permasahan yang dialaminya ketika sekolah daring, seperti halnya akan adanya suatu gangguan koneksi 
orang tua dan guru sangat terlibat aktif agar peserta didik mampu belajar dengan baik sehingga dapat berperan langsung, (ABBAS, E. R. S. I. S. 2020. Menulis).

Pembelajaran berjalan dengan baik ketika guru sudah mampu menginovasikan suatu pembelajaran dengan memanajemen pembagian waktu dengan baik, sehingga lebih efektif untuk didominasikan kepada peserta didik, sehingga menjadi kondusif sepanjang pembelajaran yang persfektifnya menjadikan lebih luas kolaboratif membuat peserta didik hanya keraguan tidak mungkin memperoleh kognitif umum, pengetahuan, keterampilan, faktual dan cakupan intelektual bisa mengubah nilai akan suatu sikap, sosial psikologi, bagi peserta didik menjadi lebih bermoral secara cukup besar dengan memperdalam kolaboratif pemahaman dalam berpikir dan belajar bagi peserta didik, (Mutiani, M., Abbas, E. W., Syaharuddin. Membangun Komunitas Belajar Melalui Lesson).

Pembelajaran kooperatif sebagai model pembelajaran membutuhkan kolaborasi, dan saling ketergantungan peserta akan menyusulkan bentukan struktur baru seperti halnya akan adanya suatu penghargaan, tujuan, dan tugas, yang dapat menekankan pembelajaran kooperatif pada modelnya akan interaksi suatu kelompok bertujuan mengembangkan interpersonal kecerdasan. Inilah diharapkan mendukung keterampilan sosial peserta didik. Sehingga peserta didik dapat menerapkan keterampilan komunikasi, bekerja, dan miliki solidaritas tinggi, (Noerkhalishah, N., Abbas, E. W., \& Permatasari. 2020. The Utilization of Tourism Education Packages).

Orang tua atau guru dapat langsung membantu dengan mendatangi ketempat peserta didik langsung kerumah bagi koneksi jaringanya yang lemah sehingga pembelajaran bisa dirasakan semua peserta didiknya dengan baik, dengan tidak lupa samasama memperhatikan jarak dan protokol saat pembelajaran berlangsung baik di lingkungan bebas atau diruangan jumlah orangnya lebih dari lima orang kiranya perlu diperhatikan rotokol kesehatan agar ketakutan akan tertularnya covid-19 terhindar jauh, (ABBAS, E. R. S. I. S. 2020. Menulis).

Sosial budaya mengkondisikan pendidikan agar berpotensi pada bahan dalam pembelajaran. Kondisi seperti ini belum pasti diyakini secara menyeleuruh dengan sepenuhnya digunakan oleh guru sebagai pendidik pada pembelajaran di sekolah yang beralihkan pada daring. Peralihan seperti ini telah direncakan secara pertimbangan baik pada pembelajaranya dengan penyesuaianya akan suatu lingkungan budaya lokal sekitar sebagai pembelajaran yang bisa diserap dalam kesesuaian penyediaan silabus agar sebagai acuan terdahhulu bisa tersusun dengan nyata. Kelanjutan nyata ditentukan dengan menentukan akan adanya suatu pembelajaran yang diukur atas dasar proaktif dengan kerja 
operasional. Selanjutnya diperankan untuk diidentifikasi oleh pendidik atas dasar sosial dan lingkungan lokal budaya sebagai sumber belajar yang relative pantas untuk dimuat dengan materi pembelajaran. (Syaharuddin, S., Rahman, A. M., \& Fitriyani, R).

Pembelajaran Sosial yang diterapkan pada keberlangsungan protokol kesehatan dapat bermakna bagi inovasi yang diterapkan pada pembelajaran ekonomi yang dapat didiskusikan peserta didik dan dirasakanya pada pembelajaran daring seperti akan adanya interaksi antara suatu kegiatan produksi dan, distribusi yang sering dirasakan peserta didik di lingkungan sekitarnya sehingga keterlibatan dengan materi ajar lainya seperti sosiologi yang dapat dilihat pada potensi budaya lokal sekitar peserta didik pada masyarakat seperti budaya pemberdayaan ekonomi dengan pengrajin pembuatan purun seperti tas ataupun bakul yang patut terus dilestarikan, (Hasanah, M. 2020. Tajau Production).

Bentuk perbandingan dari pembelajaran dilihat dari "Nilai dasar yang melatar belakangi ciri dasar masyarakat yang bertahan atas dasar inovasi budaya lokal sosial masyarakat yang patut yaitu gotong royong pembelajaran dibahas dan dimasukan dengan penerapan yang bisa ditilik dari pengambilan sikap pembelajaran materi ajar sosiologi dalam masyarakat sebagai sumber pembelajaran, mencapai kedewasaan, baik perilaku maupun kehidupan keseharian patut didorong agar mampu nanti diterapkan sebagai warga yang baik sadar akan tata cara bermasyarakat, (Subiyakto, B., \& Mutiani, M 2019).

Dengan demikian, secara tidak langsung guru memiliki beberapa tugas yang tidak bisa dielakkan, tugas guru adalah memberikan pendidikan kepada peserta didik untuk meneruskan dan mengembangkan nilai-nilai hidup Peserta didik adalah komponen masukan dalam sistem pendidikan, yang selanjutnya diproses dalam proses pendidikan, sehingga menjadi manusia yang berkualitas sesuai dengan tujuan pendidikan nasional. Sebagai suatu komponen pendidikan, peserta didik dapat ditinjau dari berbagai pendekatan (Syaharuddin, S., \& Mutiani, 2020. Strategi).

Sehingga dapat dikenalkan pada media dan pembelajaran disekolah maupun berbasis daring dapat menjadi suatu budaya lokal yang patut dibahas pada pembelajaran daring. Pendidikan mengatasi covid-19 dengan Pembelajaran yang memuat budaya lokal semakin di terapkan pada pendidikan di Indonesia diantara praktikal kegiatan merupakan sumber pembelajaran bagi pendidikan di kota Banjarmasin seperti menjadikan budaya kerajinan purun dalam pembelajaran di sekolah maupun daring pada bentuk pelajaran yang diterapkan guru seperti halnya narasi, gambar maupun variasi purun yang menjadikan bahan ajar sehingga peserta didik mengenal budaya kearifan lingkungan sekitar. 
Kearifan dikenal dengan kerajinan yang dibuat masyarakat pada muatan materi ajar dimasukan gurunya sehingga kerajinan produk lokal seperti anyaman dihargai lagi berkat pembelajaran dikenalkan dan diterapkan oleh seorang guru, Lestari, Mutiani, M. 2020. Production Activities. Lokal budaya pada pembelajaran di manfaatkan agar mempermudah peserta didik memahami pembelajaran pada new normal pada akibat covid19 dengan, menggunakan sumber pembelajaran menjadi wahana taman yang disukai dan dikunjungi peserta didik seperti halnya inovasi pembaruan guru-guru yang teribat didalam sebuah media aplikasi ajar seperti halnya ruangguru.

Nilai pendidikan mencakup pada sikap, tingkah laku berguna untuk tidak dilepas dari nilai budaya lokal yang memiliki norma, adat dan peraturan dijunjung tinggi oleh strata akan suatu bangsa didasari atas prinsip akan suatu, cita-cita dan filsafat yang berdiri tegak pada pendidikan yang dapat diterapkan pada masyarakat nantinya, (Subiyakto, B., \& Mutiani, M 2019). Agar muncul dari kegiatan keseharian dalam kepedulian dengan memfokuskan dengan kebudayaan lokal atas dasar pemahaman akan suatu konsep kepedulian, berkenaan perpaduan akan pendekatan dari budaya lokal yang membudaya pada kearifan dengan kaitanya dapat menciptakan kepedulian lingkungan pada peserta didik di masyarakat.

Inovasi seperti merubah budaya pembelajaran lebih rasional juga berpengaruh pada guru sehingga dapat memberikan peluang kerja bagi mahasiswa yang baru lulus untuk bekerja padback-nya dirasakan peserta didik agar memiliki pengetahuan baru dan privat tambahan dalam belajar, di perkuat oleh Junaidi. Inovasi lokal budaya pembelajaran kekinian sangat berguna pada masa covid-19 kini hingga membuat peserta didiknya mampu bersekolah dan, belajar dengan bahagia dan santai sehingga hal seperti inilah yang membuat peserta didik di sekolah daring menjadi lebih antusias, mulai dari paket yang disediakan dari sekolah hingga pembelajaran layaknya bermain, (Noerkhalishah, N., Abbas, E. W., \& Permatasari. 2020. The Utilization of Tourism Education Packages).

Minat belajar menjadikan priotitas utama untuk meningkatkan kualitas angka kemajuan Indonesia yang dilatar belakangi pembelajaran yang dibuat agar materi belajarnya disukai penyampaian menggunakan pendekatan tradisional dengan modern seperti layaknya pembelajaran berbasis teknologi informasi dan komunikasi yang media ajar di inovasikan dari tradional ke modern dengan penggunaan lcd berupa power point, saat guru menjelaskan kepada peserta didik dengan bahan akan adanya suatu media yang bisa digunakan untuk membentuk tujuan siswa lebih tertarik belajar akan secara sosial, (Sari, R., \& Hasanah). 
Pengaruh lain dari adanya covid-19 adalah pendidikan. Di media sosial, telah beredar di rumah dengan memanfaatkan fasilitas daring dengan fasilitas elektronik tidak mampu mengganti peran guru sebagai pendidik, pembimbing, dan pelatih. Diantara kelemahan teknologi guru mesin tidak memiliki rasa, bahasa dan karakter. Namun, hanya berperan sebagai transfer of knowledge. Karena itu, peran ini harus menjadi milik guru sebagai pendidik yang tidak hanya menjalankan fungsi transfer ilmu pengetahuan tapi juga mampu membentuk sikap dan perilaku sebagai tugas utama guru, khususnya jenjang pendidikan dasar dan menegah. Pada implementatif hal ini tidaklah mudah, (Syaharuddin, S. 2020. Menimbang Peran).

Pendekatan pembelajaran mewadahi, penguatan, latar metode pembelajaran dengan teoritis. Pembelajaran merupakan suatu kegiatan yang dippengaruhi akan rancangan suatu guru penndidik untuk memotivasi, membimbing, dan memotivasi dalam pelajaranya sehingga informasi tertentu dalam suatu proses bisa relevan disusun atas rancangan yang baik atas dasar cakupan kejadian, kandunganya mengandung serangkaian tindakan yang patut disesuaikan pada pengaruh perbuatan yang dilakukan guru atas dasar, timbal berlangsung edukatif pada situasinya, (Syaharuddin, S., \& Mutiani, Strategi).

\section{SIMPULAN}

Pendidikan Indonesia banyak mengalami perubahan terutama peran aktif yang dilakukan guru, berperan dengan memberikan inovasi pembelajaran yang semula konvensional dengan mengalihkan ke system daring, yang lebih melibatkan media teknologi informasi dan komunikasi yang di anjurkan pemerintah dan menteri pendidikan agar bisa mengurangi akan penularan covid-19 di Indonesia salah satunya dengan perubahan system pembelajaran disekolah, pembelajaran sedemikian rupa dimanfaatkan.

Budaya lokal dikaitkan guru sebagai pendidik dalam pembahasanya sehingga pembelajaran lebih terkesan mudah di amati langsung pada peserta didiknya melalui penugasan dan, materi yang cocok di lingkungan sekitar sehingga dapat dikaitkan dengan aktifitas masyarakat yang dianggap sebagai budaya dengan kearifan lokal-nya seperti halnya kerajinan yang di buat masyarakat kota Banjarmasin dengan pembuatan bakul dari material pekat dan atau purun untuk pembuatan tas dan ramah lingkungan lainya, yang dapat dijadikan pembelajaran pada masa covid-19 kini di perkuat oleh, (junaidi, 2020). 


\section{DAFTAR PUSTAKA}

ABBAS, E. W., Hidayat Putra, M. A., \& Noor Handy, M. R. (2019). Laporan Penelitian: PEMANFAATAN EKOWISATA SUNGA MARTAPURA KOTA BANJARMASIN SEBAGAI SUMBER BELAJAR IPS.

Ajidayanti, A., \& Abbas, E. W. (2019). Utilization of Tourism Bekantan Mascot as a Learning Resource On Social Studies. The Innovation of Social Studies Journal, 1(1), 78-86.

Abbas, E. W., Handy, M. R. N., Shaleh, R. M., \& Hadi, N. T. F. W. (2020). Ecotourism of Martapura River Banjarmasin as a Learning Resources on Social Studies. The Innovation of Social Studies Journal, 1(2), 111-119.

Hapijah, H., Putro, H. P. N., \& Hasanah, M. (2020). Tajau Production Activities in Kuin Utara as a Learning Resources on Social Studies. The Innovation of Social Studies Journal, 1(2), 120-128.

Lestari, J. A., Abbas, E. W., \& Mutiani, M. (2020). Production Activities of Kampung Purun Banjarbaru as a Learning Resource on Social Studies. The Innovation of Social Studies Journal, 1(2), 139-149.

Mutiani, M., WARMANSYAH ABBAS, E. R. S. I. S., Syaharuddin, S., \& Susanto, H. (2019). Penerapan Transcript Based Lesson Analyses (TBLA) Sebagai Upaya Peningkatan Pembelajaran Sejarah Di Sma Negeri 7 Banjarmasin.

Mutiani, M., Subiyakto, B., Jumriani, J., Aslamiah, A., \& Afrina, A. (2019). Laporan Penelitian: Relevansi Modal Sosial Dalam Pembelajaran IPS (Studi Kasus Dalam Sistem Zonasi Di Smp Negeri Kota Banjarmasin).

Mutiani, M., Abbas, E. W., Syaharuddin, S., \& Susanto, H. Membangun Komunitas Belajar Melalui Lesson Study Model Transcript Based Learning Analysis (TBLA) dalam Pembelajaran Sejarah. Historia: Jurnal Pendidik dan Peneliti Sejarah, 3(2), 113122.

Mutiani, R., \& Suyadi, S. (2020). Diagnosa Diskalkulia Generasi Alpha: Masalah dan Perkembangannya. Edumaspul: Jurnal Pendidikan, 4(1), 104-112.

Noerkhalishah, N., Abbas, E. W., \& Permatasari, M. A. (2020). The Utilization of Tourism Education Packages in Amanah Borneo Park as a Learning Resources on Social Studies. The Innovation of Social Studies Journal, 1(2), 158-168. 
Putro, H. P. N., \& Jumriani, J. (2020). KEHIDUPAN SOSIAL DAN EKONOMI MASYARAKAT BANTARAN SUNGAI A SEBAGAI SUMBER BELAJAR IPS.

Sari, R., \& Hasanah, M. (2019). Social Studies Based Learning Technology, Information, and Communication in SMP-SMIP 1946 Banjarmasin. The innovation of social studies journal, 1(1), 40-45.

Subiyakto, B., \& Mutiani, M. (2019). Internalisasi nilai pendidikan melalui aktivitas masyarakat sebagai sumber belajar ilmu pengetahuan sosial. Khazanah: Jurnal Studi Islam dan Humaniora, 17(1), 137-166.

Syaharuddin, S., Rahman, A. M., \& Fitriyani, R. (2019). Utilization Of Social Community as Learning Resources On Social Studies. The Kalimantan Social Studies Journal, 1(1), 18-24.

Syaharuddin, S. (2020). Menimbang Peran Teknologi dan Guru dalam Pembelajaran di Era COVID-19. Menimbang Peran Teknologi dan Guru dalam Pembelajaran di Era COVID-19.

Syaharuddin, S., \& Mutiani, M. (2020). STRATEGI PEMBELAJARAN IPS: Konsep dan Aplikasi.

Syaharuddin, S. (2020). PEMBELAJARAN MASA PANDEMI: DARI KONVENSIONAL KE DARING. PEMBELAJARAN MASA PANDEMI: DARI KONVENSIONAL KE DARING.

WARMANSYAH ABBAS, E. R. S. I. S., \& Syahruddin, S. (2018). Pembelajaran Sejarah Berbasis Sejarah Lokal di Madrasah Aliyah Negeri 3 Banjarmasin.

WARMANSYAH ABBAS, E. R. S. I. S. (2020). Menulis di Era Covid-19: Memanage Trauma Psikologis Menghindari Psikosomatis. Menulis di Era Covid-19: Memanage Trauma Psikologis Menghindari Psikosomatis.

Wahyuningsih, S., Abbas, E. W., \& Mutiani, M. (2020). Implementation of Leadership Value of Rudy Resnawan as a Learning Resources on Social Studies. The Innovation of Social Studies Journal, 1(2), 169-177. 